\title{
Assessment of Changes in the Algal Diversity of Chilika Lagoon after Opening of New Mouth to Bay of Bengal
}

\author{
Debabrata Mohanty, Siba Prasad Adhikary \\ Department of Biotechnology, Institute of Science, Visva-Bharati, Santiniketan, West Bengal, India \\ Email: adhikarysp@visva-bharati.ac.in
}

Received February 1, 2013; revised March 3, 2013; accepted April 3, 2013

Copyright (C) 2013 Debabrata Mohanty, Siba Prasad Adhikary. This is an open access article distributed under the Creative Commons Attribution License, which permits unrestricted use, distribution, and reproduction in any medium, provided the original work is properly cited.

\begin{abstract}
Eighty one algal taxa comprising of 24 species of Cyanophyta, 2 Rhodophyta, 19 Chlorophyta, 6 Euglenophyta and 30 Bacillariophyceae under Heterokontophyta were recorded in Chilika lagoon in different seasons of 2010-2011 in a survey after opening of new mouth to Bay of Bengal. Of these Cyanobacterium diachlloros, Aphanocapsa marina, Microsystis aeruginosa, Microsystis wesenbergii, Pseudanabena limnetica, Arthospira ambiguum, Oscillatoria perornata, Oscillatoria proteus, Oscillatoria simplicissima under Cyanophyta, Scenedesmus bijugatus, Urenema elongatum under Chlorophyata, Trachelomonas abrupt, Trachelomonas hispida under Euglenopyta and Coscinodiscus subtilis, Navicula amphirhynchus, Navicula major, Gomphonema micropus, Gomphonema olivaceu, Gomphonema sphaerophorum, Cyclotella meneghiniana, Pinnularia subsimilis, Pleurosigma javanicum, Stephanophyxis turris, Synendra tabulata, Stauroneis pusilla and Cymbella affinis under Bacillariophyceae of Heterokontophyta recorded in the survey have not been reported in the lake before opening of the mouth. Maximum number of algal species was observed in winter followed by summer and post monsoon seasons. Northern sector showed maximum algal diversity followed by Central, Southern and Outer channel sectors. The Cyanophytes followed by Chlorophytes were rich in Northern, Central and Southern sectors where as the diatoms were abundant in Outer channel sector and Northern sector. The agarophyte Gracilaria verrucosa recorded in the Outer channel sector of the lagoon for the first time showing extended distribution of the species due to increase in salinity coupled with consistent wave action in the lagoon after opening of the new mouth.
\end{abstract}

Keywords: Chilika Lagoon; Algal Diversity; New Mouth; Salinity Gradient; Seasonality

\section{Introduction}

Chilika lagoon in the east coast of India is the largest brackish water lake with an average depth of approximately $2 \mathrm{~m}$ and an area varies from 1165 to $906 \mathrm{~km}^{2}$ during rainy and summer seasons respectively [1]. It was declared as Ramsar site, a wetland of international importance in 1981. The fresh water input into the lagoon is from Daya and Bhargabi rivers, several other rivulets and also salt water from Bay of Bengal. Due to confluence of fresh and salt water, a distinct salinity gradient is maintained in different seasons in the lagoon ranging from 1 33 ppt basing on which it is divided into four sectors i.e. Southern, Central, Northern and Outer channel sector. Prior to 2001 in Southern sector the salinity was moderate $(8-20 \mathrm{ppt})$, in Central sector showed a seasonal variation in salinity level $(5-30 \mathrm{ppt})$ and in the Northern sector the salinity was low varying from $(0.1-13 \mathrm{ppt})$ due to opening of several rivers. Due to tidal impact, coupled with closure of the mouth connecting to the sea the salinity level in the Outer channel sector was nearly similar to the seawater during most times of the year except the rainy season [1]. To restore the lagoon characteristics with appropriate flux of seawater into the lake a new mouth was dredged in 2000 in the Outer channel sector near Sipakuda area. Again in March 2008, a natural mouth was opened near Gabakunda and was subsequently widened [2]. Both these new openings to the sea facilitated extensive mixing of saltwater with freshwater resulting in a wide variation in the hydrology of the lake. Several authors have reported the changes in the physico-chemical parameters of the lagoon after opening of these new mouths [2-7], however, assessment of algal diversity changes after 2001 has not been made so far.

An assemblage of marine, brackish and freshwater ecosystems in Chilika lagoon encourages occurrence of di- 
verse group of phytoplankton, aquatic flora and fauna, hence is one of the biodiversity of hot spots in India. The phyco-diversity in the lagoon is a subject of interest since 1930s to estimate the trophic status of the lake and its direct relevance to fisheries. The algal flora of the lagoon was studied first by Biswas [8] and subsequently Roy [9], Ahmed [10], Patnaik [11,12], Raman [13] Adhikary \& Sahu [14], Rath \& Adhikary [1,15] have documented the algal flora including their seasonal variation at different salinity gradient of the lagoon.

In the present work algal forms occurring in different seasons at the four sectors of the lagoon was studied and the changes in their diversity were assessed upon comparing with the results published as a check list [15] before opening of the new mouth in 2001.

\section{Materials and Methods}

Algal taxa were sampled during summer (May 2011), post monsoon (September 2011) and winter (December 2011-January 2012) at seven different locations in the Chilika lagoon covering all the four sectors. These were SI (Mangaljodi, Northern sector), SII (Barakul, Central sector), SIII (Kalijai, Central sector), SIV (Pathara, Central sector), SV (Rambha, Southern sector), SVI (Ghantashila, Southern sector) and SVII (Sipakuda, Outer Channel sector) (Figure 1). Samples were stored in Tarson made specimen tubes, fixed on sport with $4 \%$ formalin and brought to the laboratory for analysis. For sampling of plankton a $45 \mu \mathrm{m}$ pore size plankton net was used. Attached algae, e.g. epilithic, epiphytic and epipelic forms were collected using forcep, scalpel and nylon brush. Each sample was given a voucher number and deposited at the Department of Biotechnology, Visva Bharati. Microscopic observation and microphotography was done using Olympus B47 phase contrast research microscope fitted with Nikon 4500 coolpix digital camera. The organisms were identified following Kützing [16], Huberpestalozzi [17], Desikachary [18-21], Ramanathan [22], Philipose [23], Ettl \& Gärtner [24], Komárek \& Anagnostidis $[25,26]$ and Wołowski \& Hindák [27].

\section{Results and Discussion}

\subsection{Algal Diversity in Chilika Lagoon in 2011-12}

A total of eighty one algal species were documented from seven different collection sites of Chilika lagoon during different seasons of 2011. These belonged to Cyanophyta (24 species), Rhodophyta (2 species), Chlorophyta (19 species), Euglenophyta (6 species) and Heterokontophyta under class Bacillariophyceae (30 species). Seasonal variation in the distribution of these algal species in different collection sites is given in Table $\mathbf{1}$ and Plates 1-3. Only few cyanobacterial and algal species

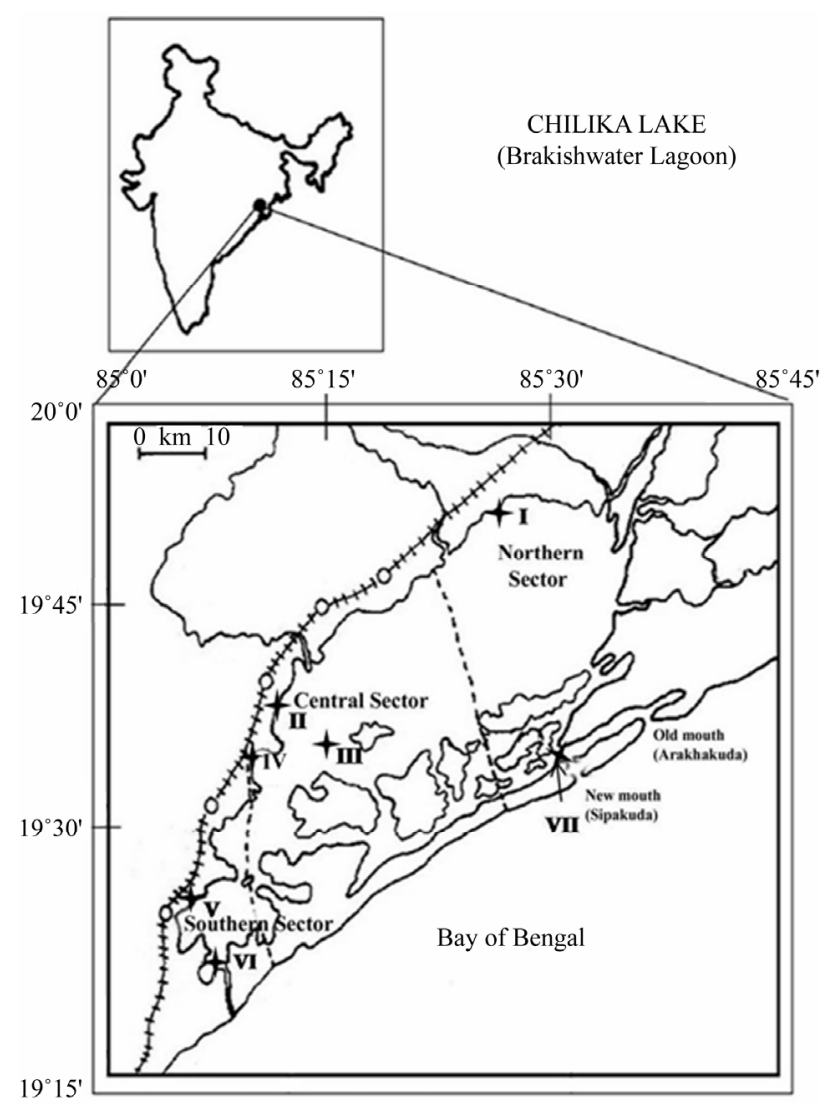

Figure 1. Map of Chilika lagoon showing sampling sites: IMangalajodi; II-Barakul; III-Kalijai; IV-Rambha; V-Pathara; VI-Ghantashila; VII-Sipakuda.

like Spirulina major (SI), Oscillatoria limosa (SV), Lyngbya aesturii (SIV), Gracillaria verrucosa (SIII, SV), Spirogyra sp. (SII, SV), Chaetomorpha linum (SV), Enteromorpha compressa (SIV), Enteromorpha intestinalis (SIV), Melosira decussata (SVII), Synedra ulna (SVII) and Amphora elliptica (SVII) were recorded consistently in specific sectors in all the seasons. During summer 59 algal species were recorded from different sectors of the lagoon. These were mostly of the class Bacillariophyceae under Heterokontophyta (21) followed by Chlorophyta (17), Cyanophyta (16), Euglenophyta (3) and Rhodophyta (2). The algal species exclusively occurred in the lake during summer were 6 Cyanophytes, 13 diatoms, 11 Chlorophytes and 2 Euglenophytes. A significant decrease in occurrence of algal taxa was observed during the post-monsoon period (September 2011) in comparison to preceeding summer (May 2011) due to flooding of riverine silted freshwater into the lake resulting in alteration in the physico-chemical characteristics of water. Totally 8 species of Cyanophyta, 1 Rhodophyta, 6 Chlorophyta, 2 Euglenophyta and 7 Bacillariophycean members occurred during post monsoon season in the lake and Pseudanabaena limnetica under Cyanophyta and Amphora elliptica under Bacillariophyta were exclu- 
Table 1. Seasonal occurrence of algal species in different locations of Chilika lagoon during 2011. SI-(Mangalajodi in Northern sector), SII-(Barakul in Central sector), SIII-(Kalijai in Central sector), SIV-(Pathara, Central sector), SV-(Rambha in Southern sector) SVI-(Ghantashila in Southern sector), SVII-(Sipakuda in Outer channel sector), S-Summer, PM-Post monsoon, W-Winter.

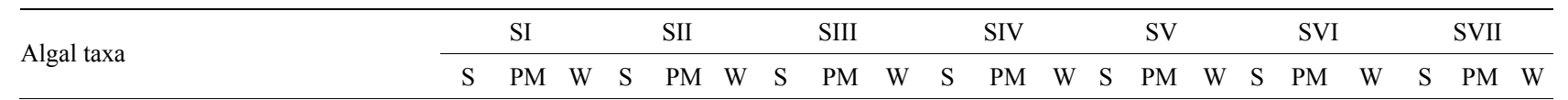

Cyanophyta

Cyanobacterium diachloros

Komárek \& Anagnostidis

Aphanocapsa marina Hansgirg

Merismopedia glauca

(Ehrenberg) Kützing

Merismopedia punctata Meyen

Merismopedia warmingiana Lagerheim

Microcystis aeruginosa Kützing

Microcystis wesenbergii (Komárek)

Chroococcus limneticus Lemmermann

Pseudanabaena limnetica Komárek

Pseudanabaena minimaAnagnostidis

Geitlerinema earlei

(Gardner) Anagnostidis

Spirulina labyrinthiformis

Kützing ex Gomont

Spirulina major Kützing ex Gomont

Spirulina subtilissima Kützing

Phormidium ambiguum Gomont

Oscillatoria limosa Agardh exomont

Oscillatoria perornata Skuja

Oscillatoria princeps

Vaucher ex Gomont

Oscillatoria proteus Skuja

Oscillatoria sanctaKützing ex Gomont

Oscillatoria simplicissima Gomont

Lyngbya aestuarii Liebman ex Gomont

Anabaena oscillarioides Bharadwaj

Anabaena variabilis

Kützing ex Bornet et Flahault

Rhodophyta

Ceramium diaphanum Roth

Gracilaria verucossa (Huds.) Papenfuss

Chlorophyta

Spirogyra sp.

Closterium venus Kützing

Chaetomorpha linum (Mueller) Kützing

Cosmarium awadhense

Prasad et Mehrotra

Cosmarium decoratum G.S. West

Cosmarium lundellii

Delponte var. ellipticum W. et G.S. West 


\section{Continued}

Cosmarium miscellum Skuja

Cosmarium punctulatum Brēbisson

Microspora willeana Lagerheim

Enteromorpha usneoides

(Bonnemaison) Agardh

Enteromorpha compressa (L.) Nees

Enteromorpha intestinalis (L.) Nees

Euastrum dubium Nägeli

Pediastrum tetras (Ehrenberg) Ralfs

Chlorella protothecoides Kützing

Scenedesmus bijugatus (Turpin) Kützing

Scenedesmus calyptratus Comas

Scenedesmus dimorphus (Turpin)

Kützing

Scenedesmus protuberans Fritsch et Rich

Uronema confervicolum Lagerheim

Uronema elongatum Hodgetts

Euglenophyta

Euglena acus Ehrenberg

Euglena agilis Carter

Euglena caudate Hübner

Lepocinclis playfairiana Deflandre

Trachelomonas abrupt Swirenko

Trachelomonas hispida Lemmermann

Bacillariophyta

Melosira decussate (Ehrenberg) Kützing +

Odontella polymorpha Kützing

Coscinodiscus marginatus Ehrenberg

Chaetoceros decipiens Cleve

Cyclotella maxima Kützing

Cyclotella meneghiniana Kützing

Fragilaria crotonensis Kitton

Synedra crystalline Kützing

Synedra radians Kützing

Synedra tabulata Kützing

Synedra ulna (Kützing) Hustedt

Tabellaria flocculosa (Roth)Kützing

Cocconeis pediculus Ehrenberg

Pinnularia nodosa (Ehrenberg) W. Smith +

Pinnularia subsimilis Gandhi

Pleurosigma javanicum Grunow

Pleurosigma normanii Ralfs

Navicula amphirhynchus Ehrenberg

Navicula major Kützing

Gomphonema micropus Kützing

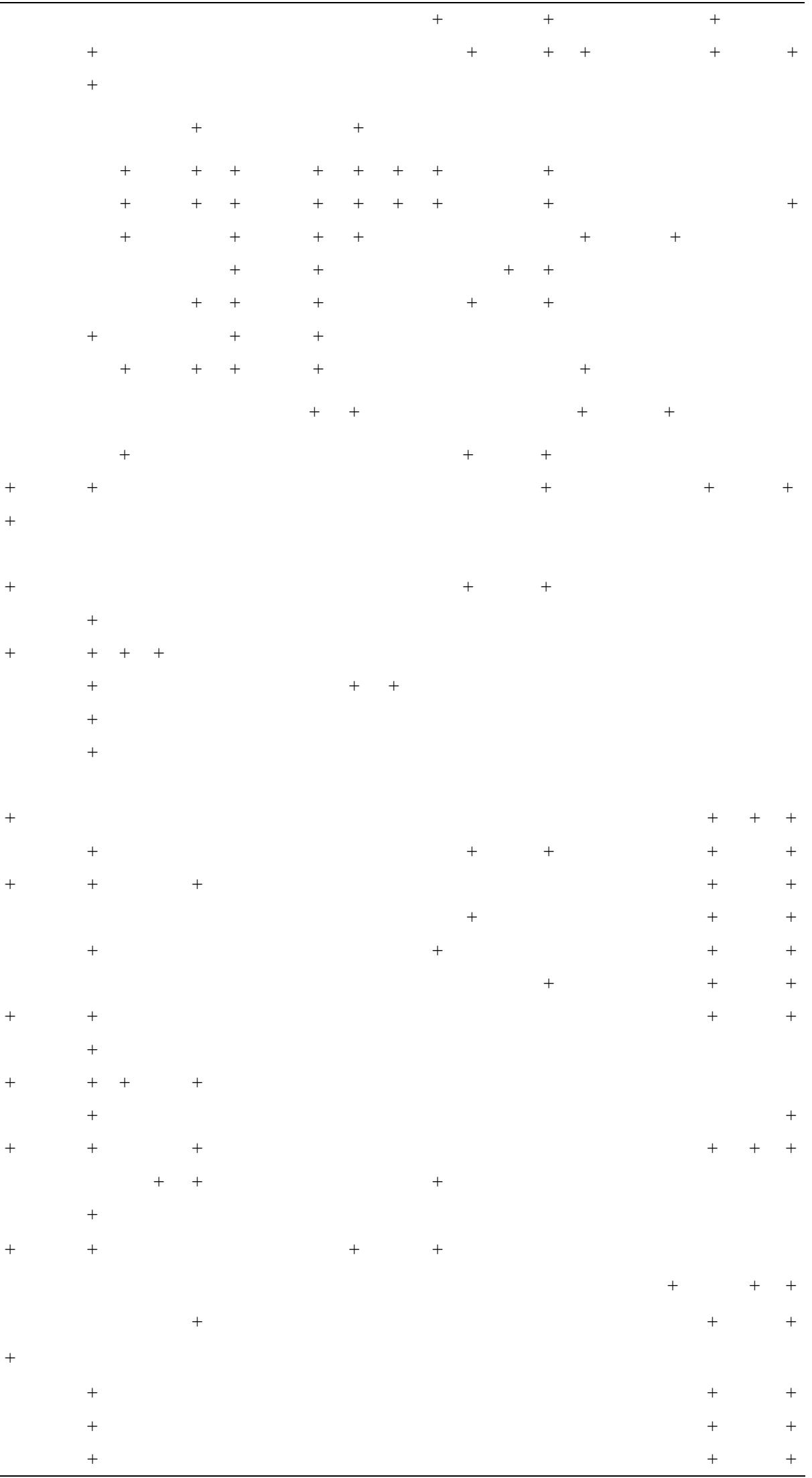


Continued

\begin{tabular}{|c|c|c|c|c|c|c|c|c|}
\hline Cymbella affinis Kützing & & & & & & + & & + \\
\hline Amphora elliptica Kützing & & & + & + & & + & + & + \\
\hline Nitzschia acuta Cleve & + & + & & & + & + & & + \\
\hline $\begin{array}{l}\text { Hantzschia amphioxys } \\
\text { (Ehrenberg) Grunow in Cleve \& Grunow }\end{array}$ & + & + & & & & + & & + \\
\hline Epithemia gibberula Grunow & + & + & & + & & + & & + \\
\hline
\end{tabular}
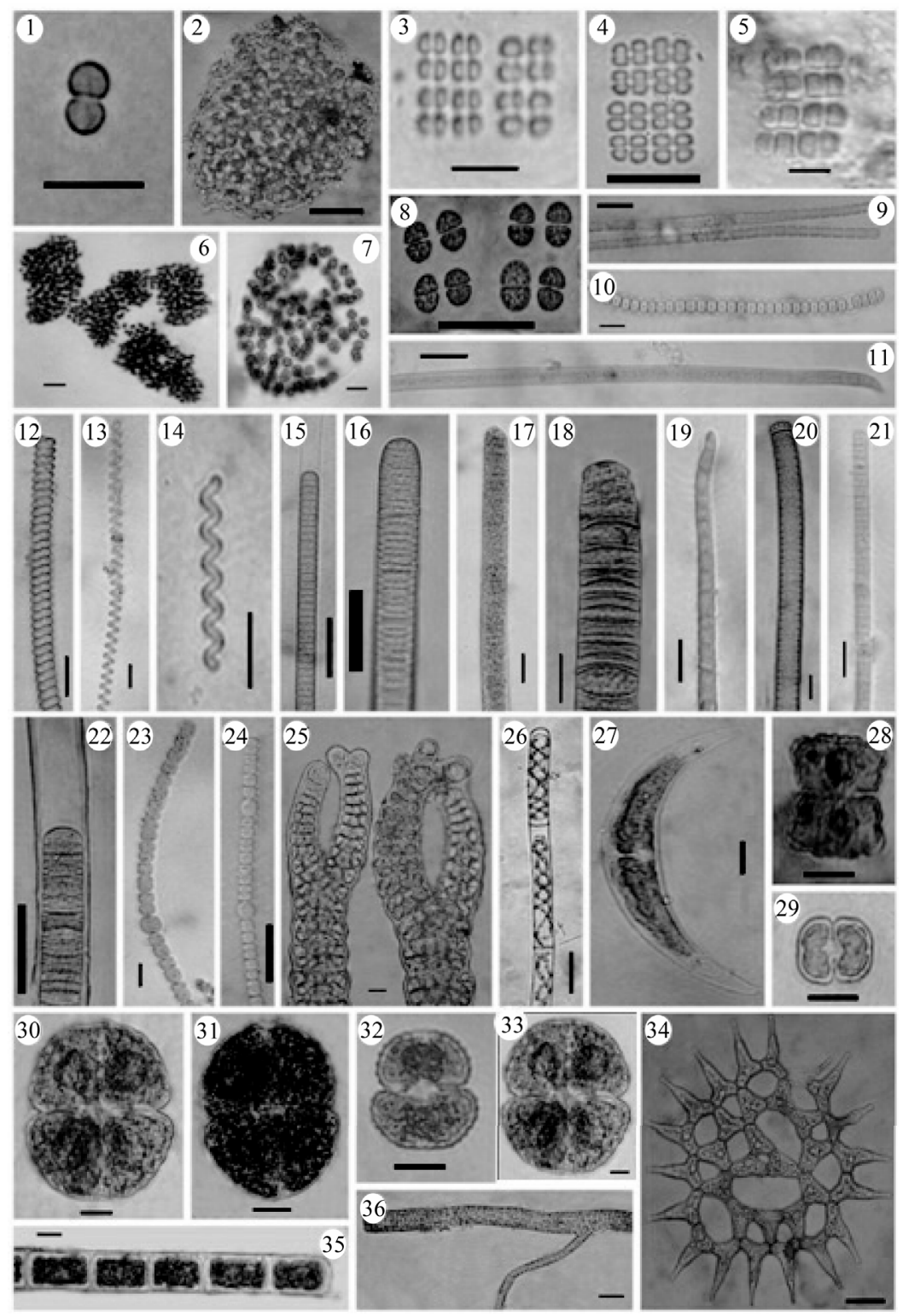

Plate 1. 1. Cyanobacterium diachloros; 2. Aphanocapsa marina; 3. Merismopedia glauca; 4. Merismopedia punctata; 5. Merismopedia warmingiana; 6. Microcystis aeruginosa; 7. Microcystis wesenbergii; 8. Chroococcus limneticus; 9. Pseudanabaena limnetica; 10. Pseudanabaena minima; 11. Geitlerinema earlei; 12. Spirulina labyrinthiformis; 13. Spirulina major; 14. Spirulina subtilissima; 15. Phormidium ambiguum; 16. Oscillatoria limosa; 17. Oscillatoria perornata; 18. Oscillatoria princeps; 19. Oscillatoria proteus; 20. Oscillatoria sancta; 21. Oscillatoria simplicissima; 22. Lyngbya aestuarii; 23. Anabaena oscillarioides; 24. Anabaena variabilis; 25. Ceramium diaphanum; 26. Spirogyra sp.; 27. Closterium venus; 28. Euastrum dubium; 29. Cosmarium awadhense; 30. Cosmarium decoratum; 31. Cosmarium lundellii var. ellipticum; 32. Cosmarium miscellum; 33. Cosmarium punctulatum; 34. Pediastrum simplex var. simplex; 35. Microspora willeana; 36. Enteromorpha usneoides (Scale bar: Figure 26, 36 = $30 \mu \mathrm{m}$; Figure 6, 31 = $20 \mu \mathrm{m}$; Figures 1-5, 7-25, 27-30, 32-35 = $10 \mu \mathrm{m}$ ). 


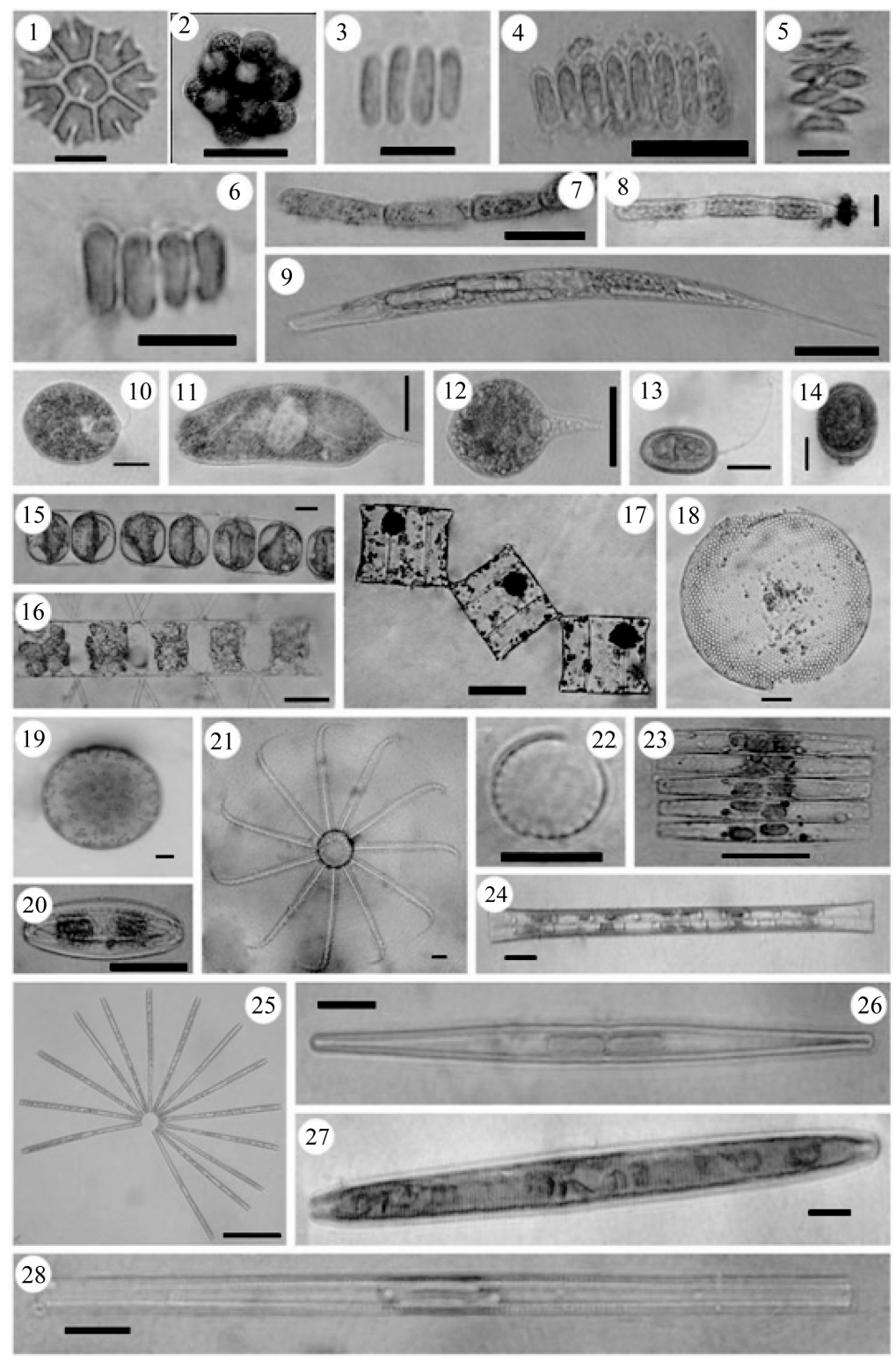

Plate 2. 1. Pediastrum tetras; 2. Chlorella protothecoides; 3. Scenedesmus bijugatus; 4. Scenedesmus calyptratus; 5. Scenedesmus dimorphus; 6. Scenedesmus protuberans; 7. Uronema confervicolum; 8. Uronema elongatum; 9. Euglena acus var. Acus; 10. Euglena agilis; 11. Euglena caudata; 12. Lepocinclis playfairiana; 13. Trachelomonas abrupta var. Abrupta; 14. Trachelomonas hispida var. Crenulatocollins; 15. Melosira decussata; 16. Chaetoceros decipiens; 17. Odontella polymorpha; 18. Coscinodiscus marginatus; 19. Coscinodiscus subtilis; 20. Cyclotella maxima; 21. Bacteriastrum hyalinum; 22. Cyclotella meneghiniana; 23. Fragilaria crotonensis; 24. Synedra crystallina; 25. Synedra radians; 26. Synedra tabulata; 27. Synedra ulna var. Aequalis; 28. Synedra ulna var. amphirhynchus (Scale bar: Figure 25 = $50 \mu \mathrm{m}$; Figure $17=40 \mu \mathrm{m}$; Figure $24=20 \mu \mathrm{m}$; Figures 1-16, 18-23, 26-28 = $10 \mu \mathrm{m})$.

cively occurred during this season. Maximum number of algal taxa comprised of 22 Cyanophytes, 2 Rhodophytes, 20 Chlorophytes, 6 Euglenophytes and 27 Bacillariophycean members occurred in the winter season. Of these, 7 species of Cyanophyta e.g. Merismopedia warmingiana, Microcystis aeruginosa, Microcystis wesenbergii, Oscillatoria perornata, Oscillatoria princeps, Oscillatoria simplicissima and Anabaena oscillarioides, 3 species of Chlorophyta e.g. Closterium venus, Cosmarium deco- ratum, Microspora willeana, 3 species of Euglenophyta e.g. Euglena agilis, Trachelomonas abrupt and Trachelomonas hispida and 4 diatom species e.g. Synendra crystalline, Synendra tabulate, Cocconeis pediculus and Gomphonema olivaceum occurred exclusively during winter months which were not recorded in the lake during summer and post monsoon period. Hence, diversity wise winter months favoured occurrence of maximum number of algae in the lagoon followed by summer and 


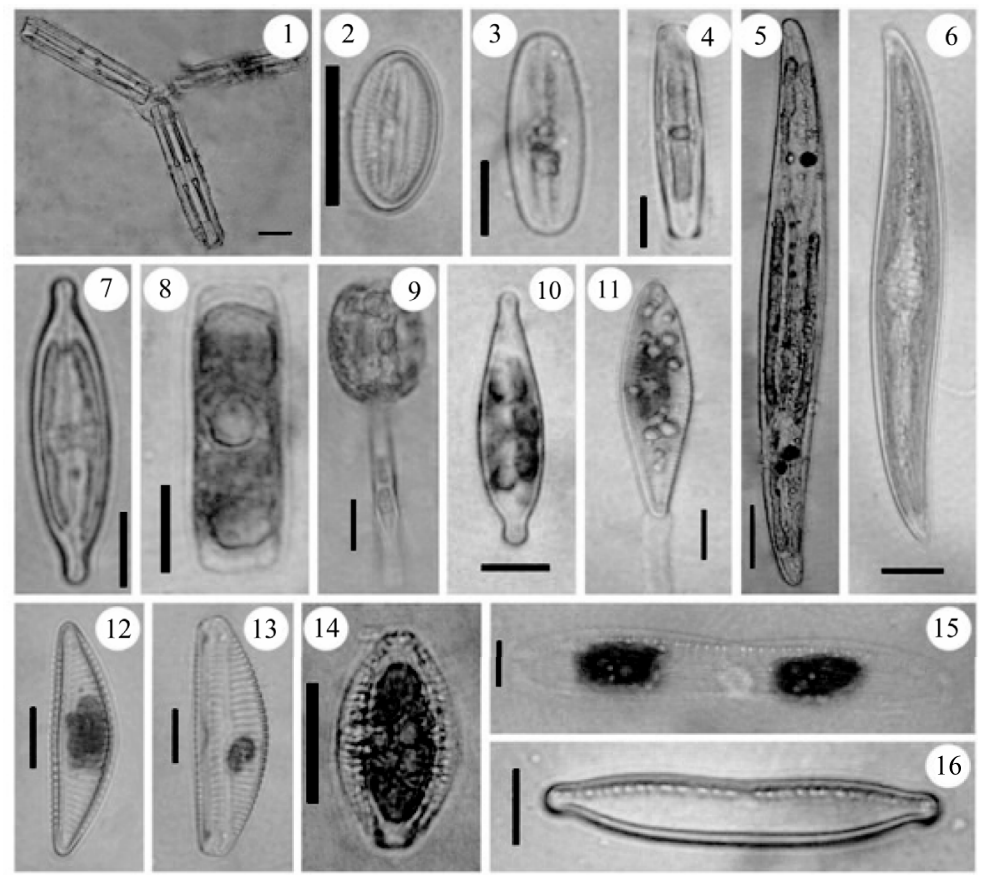

Plate 3. 1. Tabellaria flocculosa; 2. Cocconeis pediculus; 3. Pinnularia nodosa; 4. Pinnularia subsimilis; 5. Pleurosigma javanicum; 6. Pleurosigma normani; 7. Navicula amphirhynchus; 8. Navicula major; 9. Gomphonema micropus; 10. Gomphonema olivaceum; 11. Gomphonema sphaerophorum; 12. Cymbella affinis; 13. Amphora elliptica; 14. Nitzschia acuta; 15. Hantzschia amphioxys; 16. Epithemia gibberula var. producta (Scale bar: Figures 1-16 $=10 \mu \mathrm{m})$.

post monsoon period.

\subsection{Comparison of Algal Diversity in Chilika Lagoon before and after Opening of the New Mouth to Bay of Bengal}

Sector wise comparison of the algal diversity recorded in the present work with the documentation of their occurrence in different sectors of the lagoon in the immediate past 2000-2001 [1] is given in Table 2. It was observed that several algal taxa comprised of 10 Cyanophytes, 3 Chlorophytes, 2 Euglenophytes and 13 Bcillariophyce members appeared in the lagoon after opening of new mouth to the sea. These were Cyanobacterium diachlloros, Aphanocapsa marina, Microsystis aeruginosa, Microsystis wesenbergii, Pseudanabena limnetica, Arthospira ambiguum, Oscillatoria perornata, Oscillatoria proteus, Oscillatoria simplicissima, Scenedesmus bijugatus, Urenema elongatum, Trachelomonas abrupt, Trachelomonas hispida, Coscinodiscus subtilis, Navicula amphirhynchus, Navicula major, Gomphonema micropus, Gomphonema olivaceu and Gomphonema sphaerophorum in the Northern sector, Cosmarium miscellum, Cyclotella meneghiniana and Pinnularia subsimilis, in the Southern sector, Oscillatoria princeps and Pleurosigma javanicum in the Central sector and Stephanophyxis turris, Synendra tabulata, Stauroneis pusilla and Cymbella affinis in the Outer channel sector. However, the species e.g. Lyngbya aestuarii, Ceramium diaphanum, Entero- morpha usneoides, Bacteriastrum hyalinum, Nitzschia obtuse in the Sorthern sector, Pediastrumm simplex, Pediastrum tetras, Nitzschia obtusa in the Northern sector, Lyngbya aestuarii, Pediastrumm simplex, Pediastrum tetras in the Central sector and Melosira borreii, Coscinodiscus marginatus, Synendra ulna, Nitzschia obtuse in the Outer channel sector documented in the present work have also been recorded earlier in the lake in 2001 before the opening of new channel to Bay of Bengal [1]. The number of Bacillariophycean taxa which are principally benthic and epilithic increased in number in the lagoon in response to the change in the hydrological parameters especially increase in the saltwater influx to the lake.

Biswas in 1932 [8] reported first occurrence of 22 algal species comprising of Cyanophyta (11), Chlorophyta (5) and Rhodophyta (6) in Chilika lagoon. After almost 20 years Roy [9] reported 33 Bacillariophycean members in the entire lagoon. Subsequently Ahmed [10] reported 13 algal species comprised of 1 Cyanophyta, 5 Chlorophyta, 1 Bacillariophceae and 6 Rhodophyta, and Patnaik $[11,12]$ reported 57 algal species comprising 6 Cyanophyta, 8 Chlorophyta, 40 Bacillariophyceae, 7 Dinophyta, 1 Xanthophyta and 4 Rhodophyta in the lagoon. Raman [13] reported 4 species of Cyanophyta, 3 species of Chlorophyta, 10 species of Bacillariophyceae, and only 1 species of Dinophyta from the lake. Adhikary and Sahu [14] reported 9 Cyanophyta, 8 Chlorophyta, 1 Xantho- 
Table 2. Comparative account of occurrence of algal species in different sectors of Chilika lagoon recorded in present work with those occurring in 2001 [1] before opening of new mouth connecting Bay of Bengal.

\begin{tabular}{|c|c|c|c|c|c|c|c|c|}
\hline \multirow[b]{2}{*}{ Algal taxa } & \multicolumn{2}{|c|}{ Northern sector } & \multicolumn{2}{|c|}{ Central sector } & \multicolumn{2}{|c|}{ Southern sector } & \multicolumn{2}{|c|}{ Outer channel sector } \\
\hline & $\begin{array}{l}\text { Earlier } \\
\text { record }\end{array}$ & $\begin{array}{l}\text { Present } \\
\text { record }\end{array}$ & Earlier record & $\begin{array}{c}\text { Present } \\
\text { record }\end{array}$ & Earlier record & $\begin{array}{l}\text { Present } \\
\text { record }\end{array}$ & $\begin{array}{l}\text { Earlier } \\
\text { record }\end{array}$ & $\begin{array}{c}\text { Present } \\
\text { record }\end{array}$ \\
\hline \multicolumn{9}{|l|}{ Cyanophyta/Cyanoprokaryota } \\
\hline Cyanobacterium diachloros & & + & & & & + & & \\
\hline Synechocystis aquatilis & & & + & & & & & \\
\hline Aphanocapsa marina & & + & & + & & & & + \\
\hline Merismopedia elegans & & & + & & & & & \\
\hline Merismopedia glauca & + & & + & & & & & \\
\hline Merismopedia punctata & & + & & + & & + & & \\
\hline Merismopedia warmingiana & & + & & + & & + & & \\
\hline Microcystis aeruginosa & & + & & & & & & \\
\hline Microcystis wesenbergii & & + & & & & & & \\
\hline Chroococcus limneticus & & + & & & & + & & \\
\hline Chroococcus turgidus & + & & & & & & & \\
\hline Pseudanabaena limnetica & & + & & & & & & \\
\hline Pseudanabaena minima & & + & & + & & + & & \\
\hline Geitlerinema earlei & & & & + & & + & & \\
\hline Spirulina labyrinthiformis & & + & & & & + & & \\
\hline \multicolumn{9}{|l|}{ Spirulina major } \\
\hline Spirulina subtilissima & & & & & & + & & + \\
\hline Arthospira platensis & + & & + & & & & & \\
\hline Arthospira ambiguum & & + & & & & & & \\
\hline Phormidium submembranaceum & & & + & & + & & + & \\
\hline Oscillatoria limosa & & & & + & & + & & \\
\hline Oscillatoria perornata & & + & & & & & & \\
\hline Oscillatoria princeps & & & + & + & & & & \\
\hline Oscillatoria proteus & & + & & & & & & \\
\hline Oscillatoria sancta & & + & & & & + & & \\
\hline Oscillatoria simplicissima & & + & & & & & & \\
\hline Lyngbya aestuarii & & & + & + & + & + & + & \\
\hline Anabaena torulosa & + & & + & & & & + & \\
\hline Anabaena variabilis & & + & & + & & & & \\
\hline Anabaena flos-aquae & + & & + & & & & & \\
\hline Fischerella sp. & + & & + & & & & & \\
\hline Ceramium diaphanum & & & + & & + & + & + & \\
\hline Gracilaria verrucosa & & & + & + & + & + & & + \\
\hline Grateloupia filicina & & & & & + & & & \\
\hline Polysiphonia subtilissima & & & + & & + & & & \\
\hline \multicolumn{9}{|l|}{ Chlorophyta } \\
\hline Spirogyra sp. & & + & + & + & & + & & \\
\hline Chara sp. & & & & & + & & & \\
\hline NItella sp. & & & & & + & & & \\
\hline Closterium venus & & + & & & & + & & \\
\hline
\end{tabular}




\section{Continued}

Euastrum dubium

Cosmarium awadhense

Cosmarium decoratum

Cosmarium impressulum

Cosmarium lundellii

Cosmarium miscellum

Cosmarium punctulatum

Xanthidium sexmamillatum

Chaetomorpha linum

Cladophora glomerata

Ulva lactuta Linn.

Microspora willeana

Enteromorpha compressa

Enteromorpha intestinalis

Enteromorpha usneoides

Eudorina elegans

Pediastrum duplex

Pediastrum simplex

Pediastrum tetras

Chlorella protothecoides

Actinastrum hantzschii

Coelastrum cambricum

Scenedesmus bijugatus

Scenedesmus acuminatus

Scenedesmus calyptratus

Scenedesmus dimorphus

Scenedesmus protuberans

Scenedesmus qudricauda

Selenastrum gracille

Tetraedron gracile

Tetraedron trigonum

Uronema confervicolum

Uronema elongatum

Euglenophyta

Euglena acus

Euglena agilis

Euglena caudata

Leptocylindrus danicus

Lepocinclis playfairiana

Trachelomonas abrupta

Trachelomonas hispida

Bacillariophyta

Melosira borreii

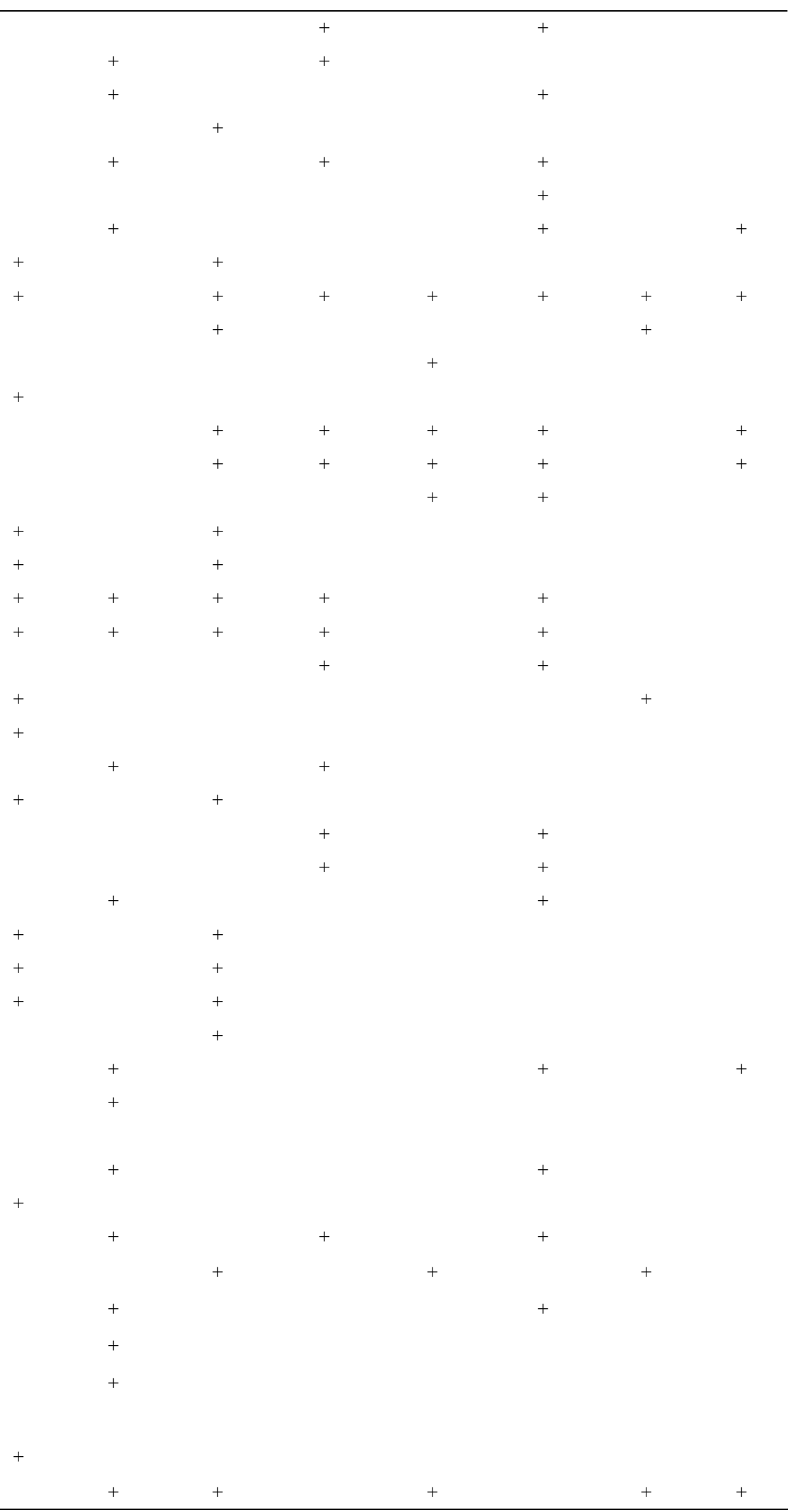




\section{Continued}

Odentella mobilensis

Odontella polymorpha

Biddulphia heteroceros

Thalassiosira subtilis

Lauderia annulata

Skeletonema costatum

Coscinodiscus centralis

Coscinodiscus gigas

Coscinodiscus marginatus

Coscinodiscus subtilis

Stephanophyxis turris

Chaetoceros affinis

Chaetoceros decipiens

Chaetoceros diversus

Chaetoceros eibenii

Chaetoceros lorenzianus

Chaetoceros paradoxus

Bacteriastrum furactum

Bacteriastrum hyalinum

Rhizosolenia setigera

Cyclotella maxima

Cyclotella meneghiniana

Fragilaria crotonensis

Grammatophora undulate

Synedra crystalline

Synedra radians

Synedra tabulata

Synedra ulna

Leptocylindrus danicus

Licmophora abbreviate

Asterionallopsis glacialis

Tabellaria fenestrata

Tabellaria flocculosa

Bacillaria paxillifera

Cylindrotheca closterium

Thallassionema nitzschioides

Cocconeis pediculus

Pinnularia alpine

Pinnularia nobilis

Pinnularia nodosa

Pinnularia subsimilis

Pleurosigma javanicum

Craticula normanii

Gyrosigma acuminatum

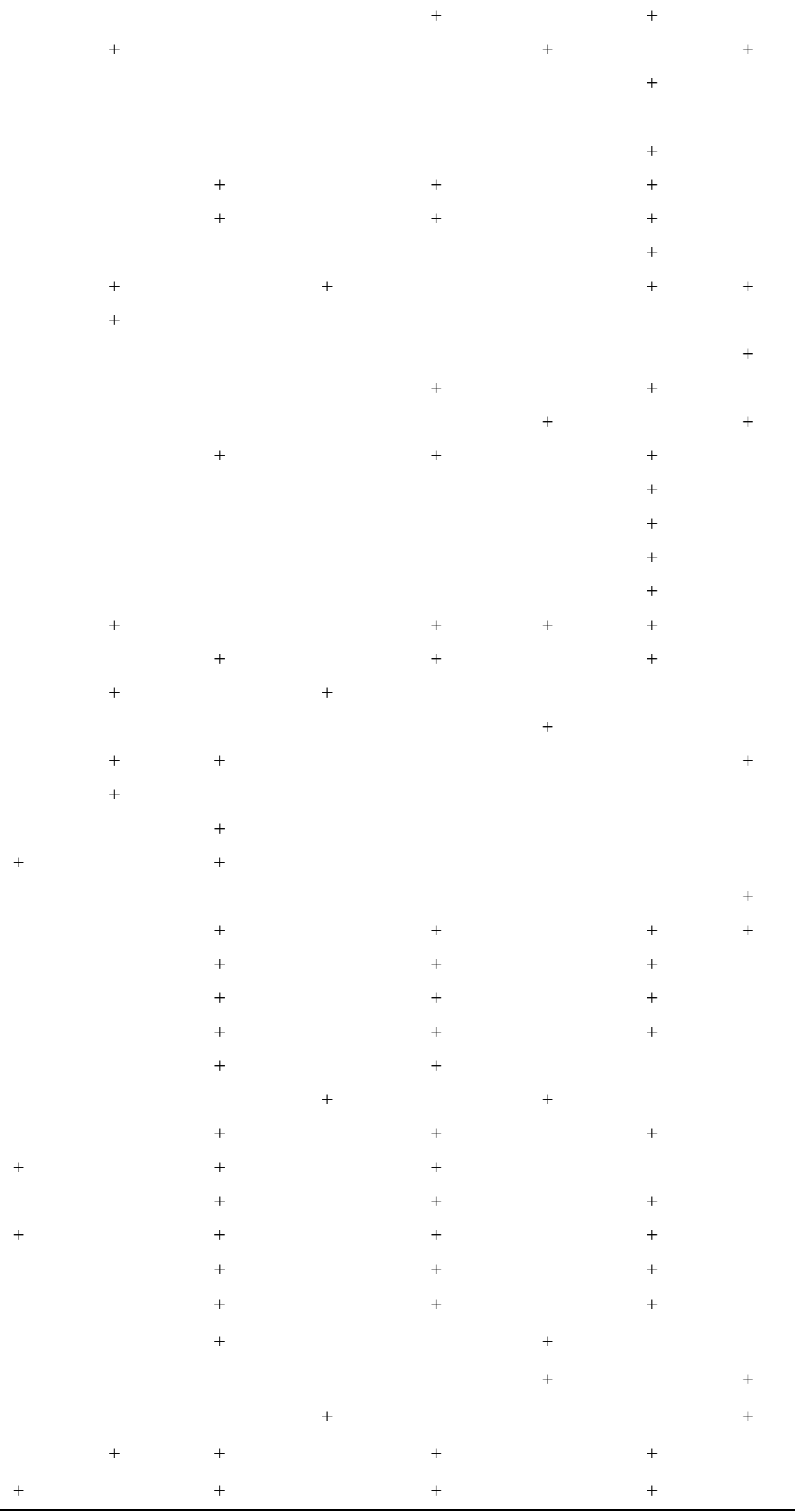




\begin{tabular}{|c|c|c|c|c|c|c|c|}
\hline Continued & & & & & & & \\
\hline Navicula amphirhynchus & & + & & + & & & \\
\hline Navicula lanceolata & & & & & & + & \\
\hline Navicula major & + & + & & & & & \\
\hline Navicula minuscula & & & + & + & & & \\
\hline Navicula protracta & & & + & + & & & \\
\hline Navicula salinarum & & & & & & + & \\
\hline Craticula cuspidate & & & & & & + & \\
\hline Gomphonema micropus & & + & & & & & \\
\hline Gomphonema olivaceum & & + & & & & & \\
\hline Gomphonema sphaerophorum & & + & + & & & & \\
\hline Stauroneis pusilla & & & & & & & + \\
\hline Cymbella affinis & & & & & & & + \\
\hline Diatoma elongate & & & + & + & & + & \\
\hline Amphora elliptica & & & & + & & + & \\
\hline Amphora ovalis & & & + & + & & + & \\
\hline Amphiprora gigantean & & & & & & + & \\
\hline Guinardia flaccid & & & + & & & & \\
\hline Nitzschia acuta & & & & + & & & \\
\hline Nitzschia obtuse & + & + & + & + & + & + & + \\
\hline Nitzschia panduriformis & + & & + & + & & + & \\
\hline Nitzschia sigma & & & & + & & & \\
\hline Hantzschia amphioxys & & + & & & & & + \\
\hline Epithemia gibberula & & + & & & + & & + \\
\hline Aulicus sculptus & & & + & & & & \\
\hline Climacosphaenia moniligera & + & & + & & & + & \\
\hline
\end{tabular}

phyta, 6 Bacillariophyta, 3 Dinophyta, and 1 Rhodophyta in the lake. Rath \& Adhikary [15] studied the diversity extensively for two consecutive years in 2000 to 2001 in different seasons and reported 102 algal species comprising 12 species of Cyanophyta, 23 species of Chlorophyta, 58 species of Bacillariophyceae, 5 species of Dinophyta, and 4 species of Rhodophyta, and published a checklist of algae of the lagoon [15]. Analysis of these reports along with those species occurred in the lake after opening of the new mouth showed that of the 81 algal taxa, 20 species were recorded in the lagoon since the first report in 1932 [8] or later in 1954 [9], 1966 [10], 1973 [11], 1978 [12], 1990 [13], 1992 [14], 1999 [28] and 2001 [15], and 61 algal taxa occurred first after opening of the new mouth. Of these, 20 species belonged to Cyanophyta, 17 to Chlorophyta, 6 to Euglenophyta and 18 to Bacillariophyceae. These finding showed that salinity increase in the lagoon due to influx of seawater through the new mouth resulted in change of the algal forms in the lagoon. Further, occurrence of 6 Euglenophyta primarily in the Northern sector and part of the Central sector at SI and SII indicated the increase in eu- trophication in the lagoon at these locations due to anthropogenic discharge by human habitation nearby. Two species of algae, of which one desmid, Closterium venus and one diatom, Chaetoceros diversus which were recorded earlier in 1973 [11] were not reported in subsequent times [15], however, appeared again in the lagoon due to increase of salinity.

\subsection{Diversity of Seaweeds in Chilika Lagoon at Different Salinity Gradient}

Occurrence of seaweeds in estuaries and lagoon is generally dependant on the salinity of the water bodies. Four species of seaweed, comprising three under Chlorophyta, Chaetomorpha linum, Enteromorpha compressa, Enteromorpha intestinalis and one under Rhodophyta, Gracilaria verrucosa were found growing luxuriantly in different sectors of Chilika lagoon. Comparative study of their qualitative and quantitative occurrence with the earlier reports $[1,28]$ showed that Chaetomorpha linum was recorded in all the sectors of the lagoon though it did not occur earlier in the Northern sector prior to opening of the new mouth. Similarly Enteromorpha compressa pre- 
sently recorded in Northern sector and Central sector at low to moderate salinity which was earlier confined to Central sector only. Enteromorpha intestinalis presently occurring all through the lake in abundance was earlier recorded in lower quantity in the Central and Southern sectors at moderate salinity levels. Growth of Gracillaria verrucosa was earlier occurring in abundance in Southern and Central sector, however, presently also appeared in Outer channel sector due to increase in salinity all through the lagoon.

Quantitative increase in the agarophyte Gracillaria verrucosa in the Southern, Central as well as in the Outer channel sector which was earlier confined only to a pocket in the Central and Southern sector of the lagoon is an important finding of the present work. Consequent upon mixing of saltwater and freshwater due to high and low tide in the Outer channel sector, and at the nearby locations in the Central sector, salinity of the lagoon increased in these area varying from $10-30$ ppt with continuous diurnal change, hence is now suitable for maximum occurrence of the agarophyte which can be harvested for use in cottage industry.

\section{Acknowledgements}

We are thankful to the Department of Science and Technology, Govt. of India for the financial support through a DST-SEED project. Thanks are due to Dr. Sudipta Kumar Das for morphometric analysis, and to the authority of Visva-Bharati for providing laboratory facility.

\section{REFERENCES}

[1] J. Rath and S. P. Adhikary, "Marine Macro-Algae of Orissa, East Coast of India," Algae, Vol. 21, 2006, pp. 49-59. doi:10.4490/ALGAE.2006.21.1.049

[2] A. P. Patra, J. K. Patra, N. K. Mahapatra, S. Das and G. C. Swain, "Seasonal Variation in Physicochemical Parameters of Chilika Lake after Opening of New Mouth near Gabakunda, Orissa, India," World Journal of Fish and Marine Sciences, Vol. 2, 2010, pp. 109-117.

[3] L. Nayak and D. P. Behera, "Seasonal Variation of Some Physicochemical Parameters of Chilika Lagoon (East Coast of India) after Opening the New Mouth, near Sipakuda," Indian Journal of Marine Science, Vol. 33, 2004, pp. 206-208.

[4] B. K. Nayak, B. C. Acharya, U. C. Panda, B. B. Nayak and S. K. Acharya, "Variation of Water Quality in Chilika Lake," Indian Journal of Marine Science, Vol. 33, 2004, pp. 164-169.

[5] A. Dube and G. Jayaraman, "Mathematical Modeling of the Seasonal Variability of Plankton in a Shallow Lagoon," Nonlinear Analysis, Vol. 69, No. 3, 2008, pp. 850865. doi:10.1016/j.na.2008.02.122

[6] R. K. Mohanty, A. Mohapatra and S. K. Mohanty, "Assessment of the Impacts of a New Artificial Lake Mouth on Hydrobiology and Fisheries of Chilika Lake, India," Lakes \& Reservoirs Research \& Management, Vol. 14, 2009, pp. 231-245. doi:10.1111/j.1440-1770.2009.00406.x

[7] S. Panigrahi, J. Wikner, R. C. Panigrahy, K. K. Satapathy and B. C. Acharya, "Variability of Nutrients and Phytoplankton Biomass in a Shallow Brackish Water Ecosystem Chilika Lagoon, India," Limnology, Vol. 10, 2009, pp. 73-85. doi:10.1007/s10201-009-0262-Z

[8] K. Biswas, "Algal Flora of the Chilika Lake," The Asiatic Society of Bengal, Vol. 11, 1932, pp. 65-198.

[9] J. C. Roy, "Periodicity of Plankton Diatoms of the Chilika Lake for the Years 1950-1951," Journal of the Bombay Natural History Society, Vol. 52, 1954, pp. 112-123.

[10] M. K. Ahmed, "Studies on Gracilaria Greu of the Chilika Lake," Bull. Orissa Fish Res. Invest, Vol. 1, 1966, pp. 46-53.

[11] S. Patnaik, "Observation on the Seasonal Fluctuating of Plankton in the Chilika Lake," The Indian Journal of Fisheries, Vol. 20, 1973, pp. 43-45.

[12] S. Patnaik, "Distribution and Seasonal Abudance of Some Algal Forms in Chilika Lake," Journal of Inland Fishary Socity of India, Vol. 10, 1978, pp. 56-67.

[13] A. V. Raman, C. H. Satyanarayan, K. Adiseshadri and K. P. Prakash, "Phytoplankton Characteristic of Chilika Lake, a Brakish Water Lagoon along the East Coast of India," Indian Journal of Marine Science, Vol. 19, 1990, pp. 274-277.

[14] S. P. Adhikary and J. K. Sahu, "Distribution and Seasonal Abudance of Algal Forms in Chilika Lake, East Coast of India," Japanese Journal of Limnology (Rikusuigaku Zasshi), Vol. 53, No. 3, 1992, pp. 197-205. doi:10.3739/rikusui.53.197

[15] J. Rath and S. P. Adhikary, "A Chick List of Algae from Chilika Lake, Orissa," Bulletin of the Botanical Survey of India, Vol. 47, 2005, pp. 101-114.

[16] F. T. Kützing, "Bracillarian Order Diatomeen," Verlag von Ferd Förstemann, Nordhausen, 1865, p. 152.

[17] P. Huber, "Das phytoplankton des Süßwassers. 2. Teil, 2. Hälfte," Schweizerbart'she Verlagsbuchhandlung, Stuttgart, 1942, p. 545.

[18] T. V. Desikachary, “Cyanophyta," I.C.A.R. Monograph on Algae, New Delhi, 1959, p. 686.

[19] T. V. Desikachary, "Atlas of Diatoms," (Diatoms from the Bay of Bengal), Madras Science Foundation, Madras. Vol. III, IV, 3-10, 1987, pp. 222-400.

[20] T. V. Desikachary, "Atlas of Diatoms," (Marine diatoms of the Indian Ocean Region). Madras Science Foundation, Madras, Vol. V, 1-3. 1988, pp. 401-621.

[21] T. V. Desikachary, "Atlas of Diatoms," (Marine diatoms of the Indian Ocean Region), Madras Science Foundation, Madras, Vol. VI, 1-13, 1989, pp. 622-809.

[22] K. R. Ramanathan, “Ulotrichales,” ICAR, New Delhi, 1964, p. 188.

[23] M. T. Philipose, "Chlorococcales," I.C.A.R. Monographs on Algae, New Delhi, 1967, p. 365.

[24] H. Ettl and G. Gärtner, "Syllabus der Boden-, Luft- und 
Flechtenalgen. Stuttgard,”New York, 1995, p. 699.

[25] J. Komárek and K. Anagnostidis, "Cyanoprokaryota I. Teil: Chroococcales. In: Herausgegeben von H. Ettl, G. Gärtner, H. Heynig, D. Mollenhauer (Eds.), SüßWasserflora," Von Mitteleuropa, Gaustav Fischer 19, 1998, p. 548.

[26] J. Komárek and K. Anagnostidis, "Cyanoprokaryota II. Teil: Oscillatoriales,” In: B. Büdel, G. Gartner, L. Krie- nitz and M. Schagerl, Eds., SüßWasserflora. Von Mitteleuropa, Elsevier, Vol. 19, 2005, p. 759.

[27] K. Wołowski and F. Hindák, "Atlas of Euglenophytes," VEDA, Publishing House of the Slovak Academy of Sciences, 2005.

[28] J. Sahu and S. P. Adhikary, "Distribution of Seaweeds in Chilika Lake," Seaweed Research Utilization, Vol. 21, 1999, pp. 55-59. 